\title{
Iron Content in Fruits, Vegetables, Herbs and Spices Samples Marketed in Sarajevo, Bosnia and Herzegovina
}

\author{
M. Bukva, D. Kapo, N. Huseinbašić, \\ S. Gojak-Salimović, and J. Huremović* \\ University of Sarajevo, Faculty of Science, Zmaja od Bosne 33-35 \\ 71000 Sarajevo, Bosnia and Herzegovina
}

This work is licensed under a
Creative Commons Attribution 4.0

International License

\begin{abstract}
Iron deficiency anaemia is one of the major health problems that affects cognitive performance, physical capacity, immune status, and reproductive performance. The iron content in 35 food samples (fruits, vegetables, herbs, and spices) marketed in Sarajevo, Bosnia and Herzegovina was determined. The iron content in the fruits and vegetables was determined using FAAS spectrometry, and in the herbs and spices samples by UV/Vis spectrophotometry. Experimentally determined content was: fruits (2.91-39.27 mg kg-1), vegetables (6.33-107 mg kg-1), herbs (135-962 mg kg-1), and spices (59.00-918 mg kg-1). Daily intakes for different plant samples were also calculated. The food samples were arranged by iron concentration in the following descending order: herbs and tea $>$ spices $>$ vegetables $>$ fruits. The results from this study were compared with previously published data. The obtained values are in the area of common values. The iron content and the factors that increase its bioavailability can help in the selection of proper foods to be included in the daily diet.
\end{abstract}

\section{Keywords}

Iron, fruits, vegetables, herbs, spices, FAAS, UV/Vis

\section{Introduction}

It is well known that a balanced diet is essential for good health. Consequently, the nutritional value of foods is a very important aspect that should be considered, particularly, with respect to metal intake, such as $\mathrm{Fe}, \mathrm{Ca}, \mathrm{Mg}, \mathrm{K}$, $\mathrm{Na}$, Se, Mn, Cu, Cr, and Zn. ${ }^{1}$ Deficiency of Fe in the body is very common, although, $\mathrm{Fe}$ is one of the most abundant elements in the Earth's crust. Iron is a component of haemoglobin present in red blood cells in the human body, and conveys oxygen throughout the body. ${ }^{2}$ The absorption of dietary Fe is a complex process which has been well investigated. Dietary Fe consists of elemental Fe, and either heme or non-heme Fe. ${ }^{3}$ It has several vital functions in the body, including oxygen supply, keeping a healthy immune system, and energy production. Iron overdose is associated with symptoms of nausea and vomiting, dizziness, diarrhoea, joint pain, and liver damage. Iron toxicity has an adverse effect on the cardiovascular system and various metabolic functions. ${ }^{4}$

Fruits and vegetables are rich sources of minerals, vitamins, and fibres, and have beneficial antioxidant effects. Fruits and vegetables are part of the daily diets in many households forming an important source of minerals and vitamins required for human health. ${ }^{5}$ Bhuvaneswari et al. ${ }^{6}$ suggested that foods, like apples, common figs, and ground nuts could be included in the diet, because they not only contain a good amount of Fe, but also ascorbic acid. Ascor-

\footnotetext{
* Corresponding author: Jasna Huremović, PhD

Email: jasnahuremovic@yahoo.com
}

bic acid has been reported as a powerful enhancer of nonheme Fe absorption, and it has been shown to reverse the inhibiting effect of, e.g., calcium. ${ }^{6}$

Spices and herbs are sources of many bioactive compounds that can improve digestion, metabolism processes, as well as food flavour. They can also contain some undesirable and harmful components, e.g., micotoxins, heavy metals, pesticides, and polycyclic carbohydrate residues. ${ }^{7}$ Beside water, tea and herb tea are the most widely consumed beverages because of their health benefits and aroma. ${ }^{8} \mathrm{~A}$ World Health Organization (WHO) survey indicated that about $70-80 \%$ of the world population relies on non-conventional medicine, mainly from herbal sources, in their primary healthcare. ${ }^{9,10}$ Various reports have discussed the potential health implications of trace metals in tea, particularly since it is known to accumulate trace metals. ${ }^{11}$

Spices are a group of esoteric food adjuncts that have been in use for thousands of years to enhance the foods sensory quality. ${ }^{12}$ While a few dozen different spice plants are of global importance, many more are used locally in the regions of their natural occurrence as condiments. ${ }^{7}$ These spice ingredients impart characteristic aroma, flavour, or colour and piquancy to foods. ${ }^{12}$ Still, spices could represent an important part of the dietary source of trace elements. A further relevant aspect is consumer safety, since some of these spices could be loaded up to a toxic level with elements to improve aspects such as colour or taste. ${ }^{13}$

In this work, the iron content of the following plants was determined: fruits (apple, blueberry, cranberry, fig, grape- 
fruit (red), grapes (red), grapes (white), nectarine, orange, and pineapple); vegetables (eggplant, beetroot, broccoli, paprika (red), potato, spinach, and zucchini); herbs (black and green tea (Camellia sinensis), chamomile (Matricaria chamomilla), elder (Sambucus nigra), mint (Mentha piperita), nettle (Urtica dioica), rosehip (Rosa canina), thyme (Thymus vulgaris)), and spices (basil (Ocimum basilicum), black pepper (Piper nigrum), dill (Anethum graveolens), ground red paprika (Capsicum annuum), minced garlic (Allium sativum), oregano (Origanum vulgare), parsley (Petroselinum crispum), rosemary (Rosmarinus officinalis), safflower (Carthamus tinctorius), turmeric (Curcuma longa)).

\section{Experimental}

\subsection{Materials and methods}

All samples were collected from different markets in Sarajevo, Bosnia and Herzegovina. Samples of fresh vegetables and fruits were collected randomly in sufficient quantities $(2 \mathrm{~kg})$ to provide representative samples. The samples were washed with tap water and rinsed with Milli-Q water to remove any soil particles attached to the plant surfaces. Samples were cut into small pieces and air-dried for two weeks, then powdered, sieved, and stored in plastic bags for iron analysis.

Iron in the fruit and vegetable samples was extracted following the acid digestion procedure: About $2 \mathrm{~g}$ of air-dried plant sample was placed into a porcelain crucible. The samples were incinerated in a muffle furnace at $470{ }^{\circ} \mathrm{C}$ for $3 \mathrm{~h}$. The ash was digested by adding $10 \mathrm{~cm}^{3}$ of mixture of concentrated $\mathrm{HNO}_{3}$ and concentrated $\mathrm{HCl}(\psi=2: 1)$, and $1 \mathrm{~cm}^{3}$ of $\mathrm{H}_{2} \mathrm{O}_{2}(\varphi=30 \%)$ was also added. After evaporation, the residue was passed through a blue band filter paper. The digest was diluted to $50 \mathrm{~cm}^{3}$ with Milli-Q water. Iron content of commonly consumed fruits and vegetables was determined by FAAS (AA240FS, Varian, Australia).

Iron in spices and herbs samples was extracted following the acid digestion procedure: About $2 \mathrm{~g}$ of crushed and homogenized plant sample was placed into a porcelain crucible. The samples were incinerated in a muffle furnace at $450{ }^{\circ} \mathrm{C}$ for $30 \mathrm{~min}$. The ash was digested by adding $4 \mathrm{~cm}^{3}$ of $\mathrm{HCl}\left(c=10 \mathrm{~mol} \mathrm{dm}^{-3}\right)$. The solution was heated at $90{ }^{\circ} \mathrm{C}$ until complete dissolution of the sample. The residue was passed through a blue band filter paper. The digest was diluted to $25 \mathrm{~cm}^{3}$ with Milli-Q water. Iron content in herbs and spices was determined by UV/Vis spectrophotometry (Carry 50, Varian, Australia), thiocyanate method.

All the chemicals and reagents were of analytical grade and purchased from Merck (Germany). Standard solution of iron was also provided by Merck. Milli-Q water was used throughout. All of the volumetric glassware was of A grade, and soaked in nitric acid $(\varphi=10 \%)$ for $12 \mathrm{~h}$ and rinsed with Milli-Q water before use. The sample and blank anal- yses were performed in triplicate, and the standard deviation was calculated. The value of the detection limit (LOD) for Fe was $0.04 \mu \mathrm{g} \mathrm{cm}^{-3}$. Spiked samples were used to test the methods at varying concentrations of analyte, and the percent recovery was calculated. The acceptable recovery of known additions was obtained (89-104\%).

Concentration of iron is expressed as the mean value $\left(\mathrm{mg} \mathrm{kg}^{-1}\right) \pm \mathrm{SD}$ of three subsamples collected from the same source.

\subsection{Daily intake}

Humans need a certain daily intake of minerals. Recommended Daily Intake, RDI value, recommended by experts and agencies for a normal adult population for iron is $15 \mathrm{mg} .{ }^{1}$

\subsubsection{Daily intake for fruit and vegetables}

Daily intake $\left(\mathrm{mg} \mathrm{kg}^{-1} \mathrm{day}^{-1}\right)$ is calculated based on the assumptions that:

1) Body weight is $60 \mathrm{~kg}$, and

2) Daily intake of fruits and vegetables is $200 \mathrm{~g}$.

Daily intake $\left(\mathrm{mg} \mathrm{kg}^{-1} \mathrm{day}^{-1}\right)=$ metal concentrations in fruits and vegetables $\times 200 / 1000 / 60 .^{14,15,16}$

\subsubsection{Daily intake for spices}

Daily intake $\left(\mathrm{mg} \mathrm{kg}^{-1}\right.$ day $\left.^{-1}\right)$ is calculated based on the assumptions that:

1) Body weight is $60 \mathrm{~kg}$, and

2) Daily intake of spices is $1.5 \mathrm{~g}$.

Daily intake $\left(\mathrm{mg} \mathrm{kg}^{-1}\right.$ day $\left.^{-1}\right)=$ metal concentrations in spices $\times 1.5 / 1000 / 60 .{ }^{17,18,19}$

\section{Results and discussion}

In this work, the Fe content was determined in the investigated plants (fruits, vegetables, herbs and spices) bought from local markets in Sarajevo. The recommended daily intake of Fe ranges from $0.27 \mathrm{mg}$ for infants, $10 \mathrm{mg}$ for children $4-8$ years of age, $11 \mathrm{mg}$ for adolescents to $8 \mathrm{mg}$ for men, and $18 \mathrm{mg}$ for women. ${ }^{19}$ Some of the plant-based foods are a good source of Fe but they may contain Fe absorption inhibitors or promoters. Depending on whether the food contains promoters or inhibitors, the bioavailability of Fe differs. The Fe content in different fruits, vegetables, herbs, and spices samples marketed in Sarajevo is presented in Table 1. 
Table 1 - Iron content $\left(\mathrm{mg} \mathrm{kg}^{-1} \pm \mathrm{SD}\right)$ in different fruits, vegetables, herbs, and spices samples marketed in Sarajevo and literature values

Tablica 1 - Sadržaj željeza $\left(m g \mathrm{~kg}^{-1} \pm \mathrm{SD}\right)$ u različitim uzorcima voća, povrća, ljekovitog bilja i začina s tržišta u Sarajevu i literaturne vrijednosti

\begin{tabular}{|c|c|c|c|c|}
\hline $\begin{array}{l}\text { Category } \\
\text { Kategorija }\end{array}$ & $\begin{array}{c}\text { Category items } \\
\text { Pojedinačni nazivi u kategoriji }\end{array}$ & $\begin{array}{l}\text { Iron content } \\
/ \mathrm{mg} \mathrm{kg}^{-1} \pm \mathrm{SD} \\
\text { Sadržaj željeza } \\
/ \mathrm{mg} \mathrm{kg}^{-1} \pm \mathrm{SD}\end{array}$ & $\begin{array}{l}\text { Calculated average daily iron } \\
\text { intake } \\
\qquad / \mathrm{mg} \mathrm{kg}^{-1} \text { day }^{-1} \\
\text { Izračunati dnevni unos željeza } \\
\quad / \mathrm{mg} \mathrm{kg}^{-1} \text { dan }^{-1}\end{array}$ & $\begin{array}{c}\text { Iron content, } \\
\text { literature values } \\
/ \mathrm{mg} \mathrm{kg}^{-1} \\
\text { Sadržaj željeza, } \\
\text { literaturne vrijednosti } / \mathrm{mg} \mathrm{kg}^{-1}\end{array}$ \\
\hline \multirow{10}{*}{$\begin{array}{l}\text { Fruits } \\
\text { Voće }\end{array}$} & $\begin{array}{l}\text { Apple } \\
\text { Jabuka }\end{array}$ & $4.10 \pm 1.76$ & 0.014 & $\begin{array}{c}8.49,,^{5} 9.2,{ }^{6} \\
14.2^{20}\end{array}$ \\
\hline & $\begin{array}{l}\text { Blueberry } \\
\text { Borovnica }\end{array}$ & $39.27 \pm 6.11$ & 0.131 & $28.12^{5}$ \\
\hline & $\begin{array}{l}\text { Cranberry } \\
\text { Brusnica }\end{array}$ & $29.12 \pm 3.55$ & 0.097 & $52.02^{5}$ \\
\hline & $\begin{array}{c}\text { Fig } \\
\text { Smokva }\end{array}$ & $2.91 \pm 1.59$ & 0.001 & $15.91,{ }^{5} 13.2^{6}$ \\
\hline & $\begin{array}{l}\text { Grapefruit (red) } \\
\text { Grejpfrut (crveni) }\end{array}$ & $8.54 \pm 4.47$ & 0.028 & $13.50,,^{5} 2.6^{21}$ \\
\hline & $\begin{array}{l}\text { Grapes (red) } \\
\text { Grožđe (crveno) }\end{array}$ & $11.91 \pm 4.45$ & 0.040 & $39.54^{5}$ \\
\hline & $\begin{array}{l}\text { Grapes (white) } \\
\text { Grožđe (bijelo) }\end{array}$ & $3.58 \pm 1.47$ & 0.012 & $12.50^{5}$ \\
\hline & $\begin{array}{l}\text { Nectarine } \\
\text { Nektarina }\end{array}$ & $3.91 \pm 2.68$ & 0.013 & $22.91^{5}$ \\
\hline & $\begin{array}{l}\text { Orange } \\
\text { Naranča }\end{array}$ & $18.85 \pm 1.55$ & 0.063 & $61.50,52.0^{21}$ \\
\hline & $\begin{array}{l}\text { Pineapple } \\
\text { Ananas }\end{array}$ & $9.00 \pm 3.18$ & 0.030 & $12.16,{ }^{5} 2.8^{21}$ \\
\hline \multirow{7}{*}{$\begin{array}{l}\text { Vegetables } \\
\text { Povrće }\end{array}$} & $\begin{array}{l}\text { Eggplant } \\
\text { Patlidžan }\end{array}$ & $31.84 \pm 1.15$ & 0.104 & $3.16,{ }^{2} 17.6^{20}$ \\
\hline & $\begin{array}{l}\text { Beetroot } \\
\text { Repa }\end{array}$ & $105 \pm 7.40$ & 0.349 & $113.31^{5}$ \\
\hline & $\begin{array}{l}\text { Broccoli } \\
\text { Brokula }\end{array}$ & $21.75 \pm 7.02$ & 0.072 & $48.99,54.7^{21}$ \\
\hline & $\begin{array}{c}\text { Paprika (red) } \\
\text { Paprika (crvena) }\end{array}$ & $8.99 \pm 6.71$ & 0.030 & $17.81^{5}$ \\
\hline & $\begin{array}{l}\text { Potato } \\
\text { Krumpir }\end{array}$ & $27.06 \pm 0.37$ & 0.090 & $22.91,{ }^{5} 19.1^{20}$ \\
\hline & $\begin{array}{l}\text { Spinach } \\
\text { Spinat }\end{array}$ & $107 \pm 0.67$ & 0.356 & $22.73,{ }^{2} 9.8,{ }^{6} 257^{20}$ \\
\hline & $\begin{array}{l}\text { Zucchini } \\
\text { Tikvica }\end{array}$ & $6.33 \pm 3.30$ & 0.021 & $28.61^{5}$ \\
\hline \multirow{8}{*}{$\begin{array}{c}\text { Herbs \& tea } \\
\text { Ljekovito } \\
\text { bilje i čaj }\end{array}$} & $\begin{array}{c}\text { Black tea } \\
\text { Crni čaj (Camellia sinensis) }\end{array}$ & $562 \pm 101$ & - & $\begin{array}{c}21.3-37.6,{ }^{22} 154.9^{23} \\
96.5^{24} 243^{25} \\
176.0-946.2^{26}\end{array}$ \\
\hline & $\begin{array}{c}\text { Green tea } \\
\text { Zeleni čaj (Camellia sinensis) }\end{array}$ & $427 \pm 27.3$ & - & $\begin{array}{c}231,{ }^{24} 135^{25} \\
242-589^{27} \\
\end{array}$ \\
\hline & $\begin{array}{c}\text { Chamomile } \\
\text { Kamilica (Matricaria chamomilla) }\end{array}$ & $135 \pm 19.2$ & - & $\begin{array}{c}188.3-581.3^{4} \\
153,{ }^{24} 521^{25}\end{array}$ \\
\hline & $\begin{array}{c}\text { Elder } \\
\text { Zova (Sambucus nigra) }\end{array}$ & $458 \pm 30.6$ & - & $79.3,^{24} 15.53-214.6^{28}$ \\
\hline & $\begin{array}{c}\text { Mint } \\
\text { Menta (Mentha piperita) }\end{array}$ & $306 \pm 62.1$ & - & $\begin{array}{c}150.57-821.02{ }^{4} \\
532,{ }^{24} 281^{25} \\
275.6-354.6^{29} \\
293^{30}\end{array}$ \\
\hline & $\begin{array}{c}\text { Nettle } \\
\text { Kopriva (Urtica dioica) }\end{array}$ & $962 \pm 92.8$ & - & $105,^{24} 999^{25}$ \\
\hline & $\begin{array}{c}\text { Rosehip } \\
\text { Šipak (Rosa canina) }\end{array}$ & $674 \pm 89.5$ & - & $\begin{array}{c}89,,^{24} 27.5,^{25} \\
150.3-230.0^{31}\end{array}$ \\
\hline & $\begin{array}{c}\text { Thyme } \\
\text { Timijan (Thymus vulgaris) }\end{array}$ & $857 \pm 57.9$ & - & $\begin{array}{c}120.75-764.51^{4} \\
822,{ }^{24} 440^{25}\end{array}$ \\
\hline
\end{tabular}


Table 1 - (continued)

Tablica 1 - (nastavak)

\begin{tabular}{|c|c|c|c|c|}
\hline $\begin{array}{l}\text { Category } \\
\text { Kategorija }\end{array}$ & $\begin{array}{c}\text { Category items } \\
\text { Pojedinačni nazivi u kategoriji }\end{array}$ & $\begin{array}{l}\text { Iron content } \\
/ \mathrm{mg} \mathrm{kg}^{-1} \pm \mathrm{SD} \\
\text { Sadržaj željeza } \\
/ \mathrm{mg} \mathrm{kg}^{-1} \pm \mathrm{SD}\end{array}$ & $\begin{array}{l}\text { Calculated average daily iron } \\
\text { intake } \\
\qquad / \mathrm{mg} \mathrm{kg}^{-1} \text { day }^{-1} \\
\text { Izračunati dnevni unos željeza } \\
\qquad / \mathrm{mg} \mathrm{kg}^{-1} \text { dan }^{-1}\end{array}$ & $\begin{array}{c}\text { Iron content, } \\
\text { literature values } \\
/ \mathrm{mg} \mathrm{kg}^{-1} \\
\text { Sadržaj željeza, } \\
\text { literaturne vrijednosti } / \mathrm{mg} \mathrm{kg}^{-1}\end{array}$ \\
\hline \multirow{10}{*}{$\begin{array}{l}\text { Spices } \\
\text { Začini }\end{array}$} & $\begin{array}{c}\text { Basil } \\
\text { Bosiljak } \\
\text { (Ocimum basilicum) }\end{array}$ & $112 \pm 65.1$ & 0.003 & $\begin{array}{c}185.73-1101.23^{4} \\
552-625^{30} \\
156.1-259.2^{32}\end{array}$ \\
\hline & $\begin{array}{c}\text { Black pepper } \\
\text { Crni papar (Piper nigrum) }\end{array}$ & $213 \pm 24.1$ & 0.005 & $\begin{array}{c}85.73,^{2} 200-984^{30} \\
11.16-19.00^{32} \\
482.28^{33}\end{array}$ \\
\hline & $\begin{array}{c}\text { Dill } \\
\text { Kopar (Anethum graveolens) }\end{array}$ & $254 \pm 49.1$ & 0.006 & $345.7^{34}$ \\
\hline & $\begin{array}{l}\text { Ground red paprika } \\
\text { Mljevena crvena paprika } \\
\text { (Capsicum annuum) }\end{array}$ & $343 \pm 27.2$ & 0.008 & $\begin{array}{l}39.9-659^{30} \\
22.9-34.5^{32} \\
70.90^{35}\end{array}$ \\
\hline & $\begin{array}{l}\text { Minced garlic } \\
\text { Mljeveni češnjak } \\
\text { (Allium sativum) }\end{array}$ & $59.00 \pm 2.71$ & 0.001 & $\begin{array}{c}54.6-69.3^{30} \\
58.6^{36}\end{array}$ \\
\hline & $\begin{array}{c}\text { Oregano } \\
\text { Origano } \\
\text { (Origanum vulgare) }\end{array}$ & $918 \pm 44.3$ & 0.023 & $\begin{array}{c}155.74-420.52^{4} \\
459-619^{30} \\
116.8-197.1,^{32} 152^{37}\end{array}$ \\
\hline & $\begin{array}{c}\text { Parsley } \\
\text { Peršin } \\
\text { (Petroselinum crispum) }\end{array}$ & $313 \pm 73.0$ & 0.008 & $\begin{array}{c}81.26-605.5^{4} \\
189-381,{ }^{30} 72.6-78.6^{32} \\
561.79^{33}\end{array}$ \\
\hline & $\begin{array}{c}\text { Rosemary } \\
\text { Ružmarin } \\
\text { (Rosmarinus officinalis) }\end{array}$ & $118 \pm 16.6$ & 0.003 & $\begin{array}{c}431.93,{ }^{23} 42.9-107.7,^{32} \\
19.4,{ }^{36} 149^{38}\end{array}$ \\
\hline & $\begin{array}{c}\text { Safflower } \\
\text { Šafranika } \\
\text { (Carthamus tinctorius) }\end{array}$ & $866 \pm 22.9$ & 0.022 & $\begin{array}{c}940.6-1663^{39} \\
255.3^{40}\end{array}$ \\
\hline & $\begin{array}{c}\text { Turmeric } \\
\text { Kurkuma } \\
\text { (Curcuma longa) }\end{array}$ & $103 \pm 12.0$ & 0.003 & $256.33,,^{33} 159.6^{40}$ \\
\hline
\end{tabular}

\subsection{Iron content in fruits}

Fruits are an important source of iron and offer advantages over dietary supplements. In daily diet, fruits have been strongly associated with reduced risk of some forms of cancer, heart disease, stroke, and other chronic ailments. ${ }^{41}$ As may be seen from Table 1, the iron content in the fruit samples ranged from 2.91 to $39.27 \mathrm{mg} \mathrm{kg}^{-1}$. The highest iron concentration was found in blueberry, followed by cranberry, orange, grapes (red), pineapple, grapefruit (red), apple, nectarine, grapes (white), and fig. According to the results of iron content in the fruits, and comparing these results with recommended daily iron intake, it seems that consumption of $200 \mathrm{~g}$ of blueberry should provide the total daily iron need for men. Comparison of our results with those of other authors showed that the iron content was similar or lower.

\subsection{Iron content in vegetables}

Vegetables constitute essential diet components by contributing proteins, vitamins, iron, calcium, and other nutrients that are in short supply. ${ }^{42}$ The iron content in the vegetable samples ranged from 6.33 to $107 \mathrm{mg} \mathrm{kg}^{-1}$. The concentration of iron varied between different vegetable samples. The samples were arranged by iron concentration in the following descending order: spinach $>$ beetroot $>$ eggplant $>$ potato $>$ broccoli $>$ paprika $($ red) $>$ zucchini. For example, according to the results of iron content in vegetables and comparing these results with recommended daily iron intake, consumption of about $200 \mathrm{~g}$ of spinach should provide the total daily iron need for women.

\subsection{Iron content in herbs and tea}

Herbal remedies are widely used for the treatment of various illnesses. They often contain highly active pharmacological components, including minerals and trace metals. ${ }^{4}$ The WHO limit for iron in medicinal herbs has yet to be established. The results of the determination of iron differed between analysed herbs and tea samples. As may be seen from Table 1, the highest level of iron was $962 \mathrm{mg} \mathrm{kg}^{-1}$, and the lowest level was $135 \mathrm{mg} \mathrm{kg}^{-1}$. The herbs and tea samples were arranged by iron concentration in the following descending order: nettle $>$ thyme $>$ rosehip $>$ black tea $>$ elder $>$ green tea $>$ mint $>$ chamomile. Comparison of our results with those of authors from other countries 


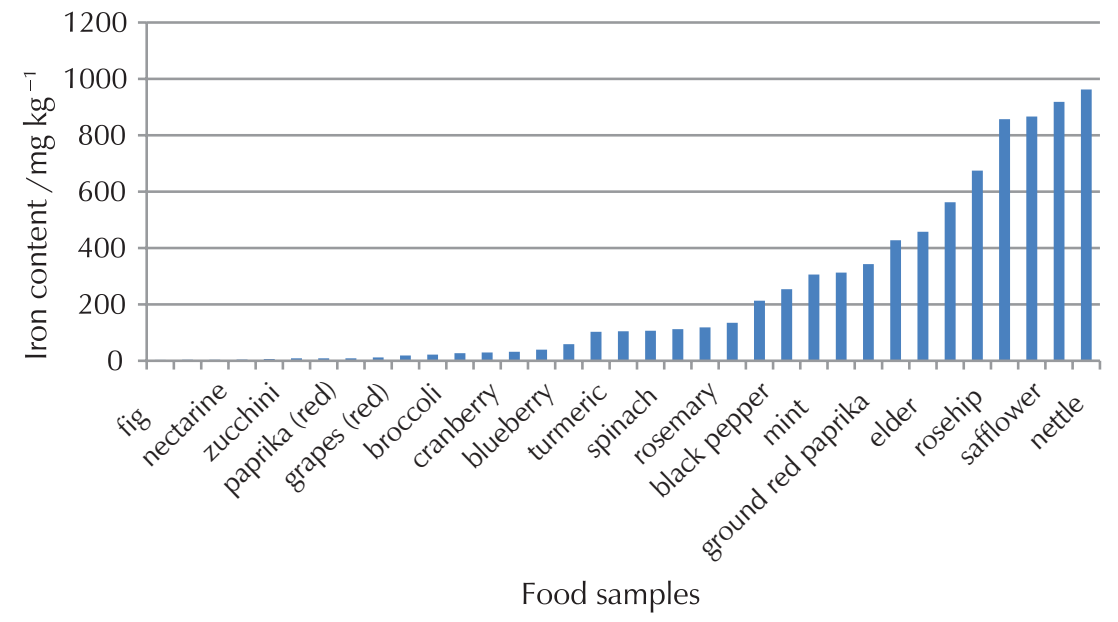

Fig. 1 - Comparison of iron content in different food samples Slika 1 - Usporedba sadržaja željeza u različitim uzorcima hrane

showed that the iron content was similar. Among the four food groups investigated in this work, herbs and tea were observed to contain the highest iron content.

\subsection{Iron content in spices}

The results of iron analysis in the selected spices samples are presented in Table 1. The observed range of iron in the current study was found between 59 and $918 \mathrm{mg} \mathrm{kg}^{-1}$. The spices were arranged by iron concentration in the following descending order: oregano $>$ safflower $>$ ground red paprika $>$ parsley $>$ dill $>$ black pepper $>$ rosemary $>$ basil $>$ turmeric $>$ minced garlic. The comparison of our results regarding iron content in the spices with those of other authors showed good agreement.

Fig. 1 shows the comparison of iron content in different food products.

\section{Conclusion}

Some of the plant-based foods are a good source of Fe, but they may contain Fe absorption inhibitors or promoters. Depending on whether the food contains promoters or inhibitors, the bioavailability of Fe differs. The iron content of 35 food samples was determined by FAAS spectrometry and UV/Vis spectrophotometry. Overall, the results showed that Fe was present in varied concentrations in fruits, vegetables, herbs, tea and spices commonly consumed in Bosnia and Herzegovina. The food samples were arranged by iron concentration in the following descending order: herbs and tea $>$ spices $>$ vegetables $>$ fruits. The results were compared with the available literature data. The obtained values are in the area of common values. The iron content and the factors that increase its bioavailability could help in selecting the proper foods to be included in the daily diet.

\section{List of abbreviations Popis kratica}

$\begin{array}{ll}\text { FAAS } & \text { - flame atomic absorption spectrometry } \\ & \text { - plamena atomska apsorpcijska spektrometrija } \\ \text { LOD } & \text { - limit of detection } \\ & \text { - granica detekcije } \\ \text { RDI } & - \text { recommended daily intake } \\ & \text { - preporučeni dnevni unos } \\ \text { SD } & \text { - standard deviation } \\ & - \text { standardna devijacija } \\ \text { UV/Vis } & - \text { ultraviolet/visible spectrometry } \\ & - \text { ultraljubičasta/vidljiva spektrometrija } \\ \text { WHO } & - \text { World Health Organization } \\ & - \text { Svjetska zdravstvena organizacija }\end{array}$

\section{References \\ Literatura}

1. M. Millikan, Nutritional metals in foods by AAS. Chapter 8: INTECH, 2012, str. 143-167, doi: https://doi. org/10.5772/27556.

2. R. Narain, V. Ilango, Analysis of iron content of selected vegetarian food items in Dubai, UAE, Int. J. Sci. Environ. Tech. 4 (3) (2015) 543-552.

3. A. Zhu, M. Kneshiro, J. D. Kaunitz, Evaluation and treatment of iron deficiency anaemia: a gastroenterological perspective, Dig. Dis. Sci. 55 (2010) 548-559, doi: https://doi. org/10.1007/s10620-009-1108-6.

4. R. Dghaim, S. Al Khatib, H. Rasool, M. A. Khan, Determination of heavy metals concentration in traditional herbs commonly consumed in the United Arab Emirates, J. Environ. Public Health. 2015 (2015) 1-6, doi: https://doi. org/10.1155/2015/973878.

5. E. Bukvić, J. Huremović, M. Memić, S. Gojak-Salimović, Heavy metals in fruits and vegetables from markets in Sarajevo, Bosnia and Herzegovina, Technologica Acta 6 (2) (2013) 29-35. 
6. S. Bhuvaneswari, M. Joshi, A. D'Souza, Quantitative analysis of iron and ascorbic acid contents in locally consumed fruits and vegetables, Int. Res. J. Biological Sci. 4 (7) (2015) $42-47$.

7. Z. Krejpcio, E. Król, S. Sionkowski, Evaluation of heavy metals contents in spices and herbs available on the Polish market, Pol. J. Environ. Stud. 16 (1) (2007) 97-100.

8. G. Karimi, M. K. Hasanzadeh, A. Nili, Z. Khashayarmanesh, Z. Samiei, F. Nazari, M. Teimuri, Concentrations and health risk of heavy metals in tea samples marketed in Iran, Pharmacologyonline 3 (2008) 164-174.

9. World Health Organization (WHO), Traditional medicine strategy 2002-2005, Geneva, 2002.

10. P. Kalny, Z. Fijałek, A. Daszczuk, P. Ostapczuk, Determination of selected microelements in polish herbs and their infusions, Sci. Total Environ. 381 (2007) 99-104, doi: https:// doi.org/10.1016/j.scitotenv.2007.03.026.

11. M. Yemane, B. S. Chandravanshi, T. Wondimu, Levels of essential and non-essential metals in leaves of the tea plant (Camellia sinensis L.) and soil of Wushwush farms, Ethiopia, Food Chem. 107 (2008) 1236-1243.

12. K. Srinivasan, Role of spices beyond food flavoring: Nutraceuticals with Multiple Health Effects, Food Rev. Int. 21 (2005) 167-188, doi: https://doi.org/10.1081/FRI-200051872.

13. C. C. Chéry, S. Herremans, V. Van Lierde, F. Vanhaecke, M. C. Freitas, R. Jasekera, Ultra-micro trace element contents in spices from Sri Lanka, J. Radioanal. Nucl. Chem. 276 (1) (2008) 143-147, doi: https://doi.org/10.1007/s10967-0070423-7.

14. Diet, nutrition and the prevention of chronic diseases. Report of joint FAO/WHO Expert Consultation, Geneva. World Health Organization. (WHO Technical Report Series). No. 916, 2003.

15. R. K. Sharma, M. Agrawal, F. M. Marshall, Heavy metals in vegetables collected from production and market sites of a tropical urban area of India, Food Chem. Toxicol. 47 (3) (2009) 583-591, doi: https://doi.org/10.1016/j.fct.2008.12.016.

16. A. Singh, R. K. Sharma, M. Agrawal, F. M. Marshall, Health risk assessment of heavy metals via dietary intake of foodstuffs from the wastewater irrigated site of a dry tropical area of India, Food Chem. Toxicol. 48 (2010) 611-619, doi: https://doi.org/10.1016/j.fct.2009.11.041.

17. H. Mubeen, I. Naeem, A. Taskeen, Z. Saddiqe, Investigations of heavy metals in commercial spices brands, N. Y. Sci. J. 2 (5) (2009) 20-26.

18. I. I. Gulzar, M. H. Lutfia, O. B. Shirwan, S. F. Sirwan, Effect of heavy metal content of some common spices available in local markets in Erbil city on human consumption, Raf. J. Sci. 23 (3) (2012) 106-114.

19. Dietry reference intakes for vitamin A, vitamin K, arsenic, boron, chromium, copper, iodine, iron manganese, molybdenum, nickel, silicon, vanadium, and zinc. National Academy Press. Washington DC [cited 2018 March 4]. Available at: www.nap.edu, 2011.

20. S. M. Abdel-Azeem, N. R. Bader, H. M. Kuss, M. F. El-Shahat, Determination of total iron in food samples after flow injection preconcentration on polyurethane foam functionalized with N,N-bis(salicylidene)-1,3-propanediamine, Food Chem. 138 (2013) 1641-1647, doi: https://doi. org/10.1016/j.foodchem.2012.11.054.

21. T. E. Siang, K. S. Chao, S. M. Shahid, Determination of iron in foods by the atomic absorption spectrophotometric and colorimetric methods, Pertanika 12 (3) (1989) 313-322.

22. Š. Mandal, B. Banjanin, I. Kujović, M. Malenica, Spectrophotometric determination of total iron content in black tea, Glas. hem. tehnol. Bosne Herceg. 44 (2015) 29-32.
23. H. S. Tercan, F. Ayanoglu, N.P. Bahadirli, Determination of heavy metal contents and some basic aspects of widely used herbal teas in Turkey, Rev. Chim. 67 (5) (2016) 1019-1022.

24. J. Ranđelović, Multielementna analiza crnog, zelenog i biljnih infuz čajeva primenom ICP-OES metode. Master thesis. Prirodno-matematički fakultet. Univerzitet u Nišu, 2013.

25. D. Kara, Evaluation of trace metal concentrations in some herbs and herbal teas by principal component analysis, Food Chem. 114 (2009) 347-354, doi: https://doi.org/10.1016/j. foodchem.2008.09.054.

26. P. L. Fernandez-Caceres, M. J. Martın, F. Pablos, A. G. Gonzalez, Differentiation of tea (Camellia sinensis) varieties and their geographical origin according to their metal content, J. Agric. Food Chem. 49 (2001) 4775-4779, doi: https://doi. org/10.1021/jf0106143.

27. A. Sykuła, K. Brodowska, M. Wiedłocha, Determination of total contents of transition metals in selected granular black teas marketed in Poland, Biotechnol. Food Sci. 78 (1) (2014) 45-52.

28. B. Kolodziej, N. Maksymiec, K. Drozdzal, J. Antonkiewicz, Effect of traffic pollution on chemical composition of rawelderberry (Sambucus nigra L.), J. Elem. 1 (2012) 67-78, doi: https://doi.org/10.5601/jelem.2012.17.1.06

29. Š. Mandal, N. Keškić, N. Marevac, The determination of iron levels in Menthae tea (Mentha piperita L.), Glas. hem. tehnol. Bosne Herceg. 48 (2017) 21-26.

30. A. Bielicka-Giełdoń, E. Ryłko, Estimation of metallic elements in herbs and spices available on the Polish market, Pol. J. Environ. Stud. 22 (4) (2013) 1251-1256.

31. S. S. Ranđelović, Bioakumulacija metala u odabranim vrstama voća i lekovitih biljaka, Doctoral thesis, Prirodno-matematički fakultet, Univerzitet u Nišu, 2015.

32. J. Huremović, B. Braha, T. Muhić-Šarac, A. Selović, M. Memić, Sadržaj teških metala u začinskom bilju s tržišta u Sarajevu, Bosna i Hercegovina, Kem. Ind. 63 (3-4) (2014) 77-81.

33. I. Jawad, Determination on heavy metals in spices and medical herbs available on the Iraq market, Adv. Environ. Bio. 10 (1) (2016) 66-69.

34. M. M. Saleh-e-ina, A. Sultanaa, M. A. Hossainb, M. Ahsanb, S. K. Royc, Macro and micro elemental analysis of Anethum Sowa L. (Dill) Stem by X-Ray fluorescence spectrometry, Bangladesh J. Sci. Ind. Res. 43 (4) (2008) 483-494, doi: https://doi.org/10.3329/bjsir.v43i4.2238.

35. A. N. Tepić, G. R. Dimić, B. L. Vujičić, Ž. S. Kevrešan, M. Varga, Z. M. Šumić, Quality of commercial ground paprika and its oleoresins, APTEFF. 39 (2008) 77-83, doi. https://doi. org/10.2298/APT0839077T.

36. B. Darko, I. Ayim, R. B. Voegborlo, Heavy metal content in mixed and unmixed seasonings on the Ghanaian market, Afr. J. Food Sci. 8 (1) (2014) 14-19, doi: https://doi.org/10.5897/ AJFS2013.1107.

37. D. Kostić, S. Mitić, A. Zarubica, M. Mitić, J. Veličković, S. Randjelović, Content of trace metals in medicinal plants and their extracts, Hem. Ind. 65 (2) (2011) 165-170, doi: https:// doi.org/10.2298/HEMIND101005075K.

38. S. Kazaz, H. Baydar, S. Erbas, Variations in chemical compositions of Rosa damascena Mill. and Rosa canina L. Fruits, Czech J. Food Sci. 27 (3) (2009) 178-184.

39. L. H. Jia, Y. Lilt, X. Z. Li, Determination of wholesome elements and heavy metals in safflower (Carthamus tinctorius L.) from Xinjiang and Henanby ICP-MS/ICP-AES, J. Pharm. Anal. 1 (2) (2011) 100-103, doi: https://doi.org/10.1016/ S2095-1779(11)70017-X

40. M. H. Matloob, Using stripping voltammetry to determine heavy metals in cooking spices used in Iraq, Pol. J. En- 
viron. Stud. 25 (5) (2016) 2057-2070, doi: https://doi. org/10.15244/pjoes/62401.

41. A. Verma, P. Sharma, N. Dhusia, N. More, Determination of heavy metal content in fruits and fruits juices consumed in urban areas of Lucknow, India, Int. J. Food Sci. Nutr. 1 (5)
(2016) 44-50.

42. M. D. Sa'eed, M. R. Abdullahi, Calcium and iron levels in some fruits and vegetables commonly consumed in Kano metropolis, Nigeria, Bayero J. Pure App. Sci. 5 (1) (2012) 57-59, doi: https://doi.org/10.4314/bajopas.v5i1.11.

\title{
SAŽETAK
}

\section{Sadržaj željeza u voću, povrću, ljekovitom bilju i začinima s tržišta u Sarajevu, Bosna i Hercegovina \\ Mersa Bukva, Delila Kapo, Nudžeima Huseinbašić Sabina Gojak-Salimović i Jasna Huremović*}

\begin{abstract}
Anemija zbog nedostatka željeza, jedan je od glavnih zdravstvenih problema, a utječe na kognitivne sposobnosti, fizički kapacitet, imunološki status i reproduktivnu sposobnost. Utvrđen je sadržaj željeza u ukupno 35 uzoraka hrane (voće, povrće, ljekovito bilje i začini) s tržišta u Sarajevu u Bosni i Hercegovini. Sadržaj željeza u voću i povrću određen je FAAS spektrometrijom, a u uzorcima ljekovitog bilja i začina UV/Vis spektrofotometrijom. Utvrđen je sljedeći sadržaj: voće $\left(2,91-39,27 \mathrm{mg} \mathrm{kg}^{-1}\right)$, povrće $\left(6,33-107 \mathrm{mg} \mathrm{kg}^{-1}\right)$, ljekovito bilje $\left(135\right.$ - $\left.962 \mathrm{mg} \mathrm{kg}^{-1}\right)$ i začini $\left(59,00-918 \mathrm{mg} \mathrm{kg}^{-1}\right)$. Također su izračunati dnevni unosi za različite uzorke biljnog materijala. Prema koncentracijama željeza uzorci su raspoređeni u sljedećim serijama: ljekovito bilje > začini $>$ povrće > voće. Rezultati ovog istraživanja uspoređeni su s prethodno objavljenim podatcima. Dobivene vrijednosti nalaze se u području literaturnih podataka. Sadržaj željeza i čimbenici koji povećavaju njegovu bioraspoloživost mogu pomoći u odabiru odgovarajuće hrane za svakodnevnu prehranu.
\end{abstract}

Ključne riječi

Željezo, voće, povrće, ljekovito bilje, začini, FAAS, UV/Vis

Odsjek za hemiju, Univerzitet u Sarajevu,

Izvorni znanstveni rad Prirodno-matematički fakultet

Zmaja od Bosne 33-35

71000 Sarajevo

Bosna i Hercegovina

Prispjelo 7. siječnja 2019.

Prihvaćeno 12. veljače 2019. 